\title{
THE ROLE OF INTERNET AND SOCIAL MEDIA IN RECRUITMENT IN CERTAIN ISLAMIC TERRORIST ORGANIZATIONS. CASES OF AL QAEDA AND ISIS
}

\author{
Ruslana Grosu ${ }^{1}$ and Vasile Bubuioc ${ }^{2}$
}

\begin{abstract}
This research is an attempt to resume and elucidate the practical valence of the academic works, published in the Western countries and Russia. The main goal of this study was to substantiate, in terms of theoretical and methodological aspect, the contents of publications, which reflect a wide range of topics, such as the propaganda, manipulation and recruitment in the terrorist organizations through the social media and the Internet, accentuating the psychosocial components, and highlighting the practices to combat this phenomenon.
\end{abstract}

The paper focuses on the issue that the Internet and global networks significantly increased the potential for terrorist organizations Al Qaeda and ISIS to carry out their criminal plans. The authors based their research on the thesis that global network represents a new virtual environment, favourable for the online criminal acts, including the recruitment in the terrorist organizations such as Al Qaeda and ISIS. They use the Internet as means of psychological warfare through the dissemination of disinformation and horror, for recruitment of new members.

The researchers underlined the amplification of the recruitment through various social networks. The anonymity and a large audience allow different interest groups, regardless of their place of residence, an uncontrollable and secret communication. The recruitment in the cyber terrorist communities has been conducted in online form by identifying and attracting people interested to support the approach and actions of the terrorist organizations such as ISIS and Al Qaeda.

Key words: social media, networks, Internet, recruitment, terrorist organizations, Al Qaeda, ISIS.

Terrorism is considered the gravest form of contemporary breaking of the law, presenting a threat to the international peace and security, reason for which the fight against it requires the joint efforts of all world countries. In the $21^{\text {st }}$ century, this phenomenon, quantitatively and qualitatively, differs from terrorism of "the previous generation" by not only increasing of the threats that bear the terrorist groups, the variety of action strategies and types of terrorist actions, the most modern and sophisticated technical equipment, the types of motivation, and the number of victims. Yet, it became more ominous by the recruiting methods that appeal to the advanced technologies to implement the criminal aims of the terrorist organizations.

The United Nations has included terrorism among international crimes, developing certain legal instruments (conventions, resolutions, etc.) that led to adopt the practical measures to prevent and combat terrorism. [5] The international legal regulation of the fight against terrorism was done both,

\footnotetext{
${ }^{1}$ Doctor of Political Sciences, Institute of Legal and Political Research of Academy of Sciences of Moldova

${ }^{2} \mathrm{PhD}$ student, “Alexandru cel Bun” Armed Forces Military Academy, Republic of Moldova
} 
internationally, at the UN level, and, regionally, at the level of the Council of the European Union, the US and Arab countries.

It is important to mention that in 2002 the Council of the European Union had adopted the Framework Decision 2002/475/JHA of 13 June 2002 on combating the terrorism referring mostly to the common definition of terrorist act accepted by all EU members and some specific aspects. In response to increasing the terrorist threats, including the use of new information technologies, social networks and the Internet, the Framework Decision 2002/475/JHA was amended in 2008 [7] including provisions specifically on public provocation to commit the terrorist offenses, recruitment, training or granting of other support for terrorist purposes. In this decision, the Council of the EU has taken into consideration the Resolution 1624 (2005) issued by UN Security Council, the Council requiring the EU member states to take measures to prohibit by law the incitement to commit a terrorist act and to prevent such behaviour.

Currently, the role of the social networks and the Internet remains significant, as these tools can be used not only as some cheap, fast and effective means to publish written, audio and video messages with an extremist rhetoric, but also to recruit new members in terrorist organizations, as well as a way to engage with an audience prone to be manipulated and influenced by pro-terrorist propaganda. In the same context, it should be mentioned that the leaders of international terrorism are waging a very hard informational war through the media, and for an easy success have created an enough extensive network that produces a colossal impact on the public, using, as previously there was mentioned, the most modern communication systems, especially the Internet. According to P. Volosyuk's opinion, the information systems development and applications for global communication create a number of challenges in ensuring the national security, and they are often used to recruit suicide-bombers or to control the terrorist acts. [17, p. 90]

In C. Bockstette' point of view, the Internet has two roles in relation to media: primary and secondary. The major one refers to its status in the interaction between recruiter and potential member, the Internet becoming the main way for messaging the propaganda, while the methods of broadcasting by media are secondary. [3, p. 17]

The modern opportunities offered by Internet to disseminate the information and its informational impact are superior to that of the media due to the following features: a relatively inexpensive and simple 24/24 access for a large volume of information, regularity and efficiency on the location and sites content changes, the rapid flow of information, the lack of regulation, the number of users in continuing rising. For example, in 2011, according to data provided by Z. Beshukova, the number of Internet users has risen to 2.4 billion, which indicates that one third of the world population has access to Internet, while in 2008 this possibility was enjoyed by less than $20 \%$ of the population. $[14$, p. 265]

A widely discussed topic in academic works is the method used by the terrorist organizations to recruit new members through the social networks and the Internet. In fact, T.L. Thomas approached and described the issue of cyber strategy very detailed, more exactly the Internet using by terrorist organizations, his research being complemented by the article "Al Qaeda and the Internet: The Danger of "Cyberplanning"", which focuses on 16 possible ways of virtual network use by terrorist organizations. [11] In this regard, G. Weymann, quoted by M. Conway, distinguished eight methods by which the terrorist organizations already are accessing the Internet. This fact is confirmed by resorting to psychological war, data searching, fund raising, recruitment and mobilization, networking, information sharing, planning and coordination. In the same context, M. Conway 
concluded that methods of Internet use by terrorist organizations have been defined by different authors, which are largely similar, and in spite of the fact that researchers have proposed 22 ways, the experts have often used different terms to refer to same method. [4, p. 3] Given these coincidences, the following analysis is based upon the identification of five ways to use the Internet for the terrorist organizations: 1) information providing; 2) funding; 3) networking; 4) recruitment and 5) information gathering. Each of the authors mentions the resources' production and information providing, particularly the propaganda by the terrorist organizations, having the Internet as the main means. The author summarizes some uses, including secure communication and planning in the process of "network building". In addition, while regarding the recruitment there were pronounced only two researchers, quoted by M. Conway, such as T. L. Thomas and G. Weymann [4], we note that several authors who have approached these views expressed that the Internet is used to promote the terrorist activity, attracting new members in terrorist organizations.

Referring to the use of the Internet by terrorist organizations, M. Conway made reference to the research developed by S. Fernely and M. Worren, who wrote in 1999 that their main methods were resorting to propaganda or advertising on the Internet, funds collecting, information disseminating, secure communication, and, in addition, the same list was presented by F. Cohen in 2002.

In this regard, researchers S. Gerwehr and S. Daly mentioned that the terrorist organizations frequently used the propaganda, disseminated through certain virtual platforms, such as web pages and chats protected by limited and secured access as means of a secret recruitment. [9, p. 83] There are opinions that the terrorist propaganda is often intentionally designed to create an attractive image of terrorist organizations in front of the vulnerable and marginalized groups of society.

Analysing the dynamics proposed by M. Musaev and I. Abdulaev, there were identified several stages, the first and second of which were not relevant to that study. The authors have focused attention on the third stage - the propaganda through the websites [20, p. 52], because, as we mentioned earlier, in the mid-2000, the Internet quickly entered the daily life, becoming one of the most important sources of information, beyond television and other forms of communication. So, it has become the most convenient and cheapest tool of propaganda for clandestine activity of terrorist organizations and extremist groups. That method of recruitment was intended to expand the possibilities of changing the consciousness of the individual by resizing and strengthening of the morality models. As other researcher remarked, in 1998 there were only 12 sites, in 2005 their number reached already 4800 (in different languages), while in 2016 - over 10000 sites, about 200 are in Russian language). [19, p. 100] Referring to the fourth stage - the propaganda through the social networks, it has become a substitute for real communication, as M. Musaev and I. Abdulaev stated [20, p. 52].

Regarding the recruitment process through the Internet, various social networks, mobilizing the supporters to actively encourage the terrorist activities, M. Conway illustrated the procedure by emphasizing that the Internet provides many ways to do: the information became more accessible to be collected by potential "recruits", which is a larger volume of data collected and transmitted much faster in multimedia format; the global networks allow the groups to promote themselves to a large number of people. [4] As a result of growing the capabilities of interactive communications, there appeared a serious opportunity to promote groups and even directly contact with them.

In the context of new members' recruitment by terrorist organizations, N. Golyandin and A. Goryachev noted the same idea to be actively practiced through the Internet and various social networks. The researchers have identified certain features of Internet such as anonymity and the 
simultaneous access to a quite wide audience in the absence of the society "censorship", enabling certain interest groups, regardless of their location, to communicate in secret without any control. However, professor I. Sundiev, quoted by previous authors, has underlined that the information technologies ensure the terrorist organizations both resources and influences at global level, but also a range of operating with a very low degree to be discovered. Since most of the terrorist organizations have given up a physical space for meetings, they have resorted to create the virtual communities, through chats and web pages continuing to disseminate the propaganda and trainings. $[18$, p. 37-38]

The increasing coverage area of the Internet provides to terrorist organizations and their supporters a globally expanded ground to recruit its potential militants. There would be important to note the forums with restricted access that have become for the new recruits, according to D. E. Denning, a secured space where they can get information about the terrorist organizations giving support, and then they continue shortly with measures to promote the objectives of terrorist activity. [6, p. 198] Finally, using the forums there could be drawn into public debate either supporters or opponents of this group, which could help terrorist groups to identify their position and their tactics eventually to increase, generally, the support and attractiveness.

If initially this study was based mainly on theoretical assertions, then one of the opinions of the military caste representatives, especially that of C. Bockstette, expressed a similar position, just highlighting the peculiarities of this process in terms of the strategic and asymmetrical propaganda through the information technologies. The author analysed in this respect other opinions according to which the recruitment rhetoric is simple: by the counter-hatred of notions guilt and humiliation of honour, duty and dignity. [3, p. 12] The theoretical aspect of the study is outlined with references to the theory of M. Sageman, due to which recruits often do exactly what others do, his research being focused on recruiting in the terrorist organization Al-Qaeda, because in 2010 the terrorist organization "Islamic State" (ISIS) did not exist. [3, p. 15]

Regarding the recruitment methods, C. Bockstette wrote in 2010 that terrorists don't have a central organization to handle the recruitment of new members, and for this reason, in addition to traditional recruitment methods (prayers, sermons in mosques and religious schools, media), the Internet holds their top, new members paying attention and time to Internet and social networks. In order to stimulate the transformation of Muslims and non-Muslims in their followers, the recruiters of the terrorist organizations resort to launching certain ideas to inspire them to "radicalization". The social networks and dynamics within the group, especially as pressure from the members of movement plays an important role in forming close emotional ties. [3, p. 11] Already there were known the cases of declared terrorists as the most dangerous in the world, who previously didn't show a special activism, but they were ordinary members, who led a common life, going through a period of deep crisis and a long search of themselves.

The recruiting of new members in virtual communities is made online, i.e. within a system of measures to identify and attract different groups of people, being interested to actively support the opinions and actions of terrorist organizations members. At the initial stage, according to the N. Golyandin and A. Goryachev, the visitor of the site or the forum is brought into debate whether he supports or rejects the views of the site owner, which gives to recruiters the opportunity to enhance discussions and attractiveness, generally, creating the impression of a real support in some discussions. [18, p. 37-38] In the recruitment and radicalization of terrorists, as mentioned by the experts of the European Commission in the field of violent radicalization, there was seeking the tendency to raise a person's feeling of injustice, exclusion or humiliation. [8] 
If a potential recruit is not sure to join the group, or the group does not inspire total confidence, he/she is tested in a chat, and if he/she passes the exam, he/she is redirected to another chat to further investigation and possibly could be considered able of direct contact with a group's member. The purpose of this process is a way to select the inappropriate individuals or some undercover intelligence agents and the law enforcement agencies with responsibilities in preventing and combating the terrorism.

There are some suppositions that the online recruiting in the terrorist organizations is widespread, and as example M. Conway brought an Iranian site, as having an attractive source of a selfmurdered terrorist' application. [4, p. 13] The propaganda can be adapted to take into account the demographic factors such as the age or gender, and social or economic circumstances. The contribution of A. Rakhmonov was valuable in identifying, in terms of internal and external psychological factors, which led to the young people involvement in terrorist organizations, particularly in the Central-Asian countries, member states of Collective Security Treaty Organization and the Shanghai Cooperation Organization, stressing that the main places and channels for recruitment remain the cyber communities, virtual clubs and social networks (Odnoklassniki, Facebook, YouTube, specialized sites). [22, p. 145]

In recruiting young people, who constitute the majority of network users, the Internet is the most effective way, and the form, in which this is achieved, varies depending on the creativity of recruiters from popular cartoons, videos, music to computer games. The tactics used on websites are managed by some terrorist organizations or associated ones in order to recruit minors, including the use of a mix of cartoons and children' stories with messages that promote the acts of terrorism glorification, such as missions of self-murderer terrorists.

Similarly, certain terrorist organizations develop video games online, to use as a tool in recruiting and training of the beginners. In G. Weimann's opinion, such games can serve as a means of violence' propaganda against the state or officials, offering a reward for the virtual success and can be translated into various languages in order to attract diverse groups of passionate people. [13] In the same context, as N. Golyandin and A. Goryachev pointed out, it became the implementation and expansion of computer games online networks, such as "The Great Game. Break the system", "Falcon. World after the racial war". [18, p. 37-38]

A likewise idea was expressed by M. Musaev and I. Abdulaev, who presented for discussion the model for recruiting in the terrorist organization "Islamic State", clarifying the means and methods of manipulation of ISIS group recruiters and their impact on the consciousness in psychological aspect. [20, p. 52] Many potential recruits get information about ISIS firstly, by media, and, secondly, seek the information on social networking pages.

Regarding the phenomenon of online recruitment practices through the ISIS, R. Torok related with a retrospective on its ascent through the recruitment mechanisms of skilfully using the most popular social networks Facebook, Twitter, and audio-video platforms such YouTube as well. [12]

As the researcher M. Berger noted, the international community remains concerned about the consequences of online hidden activities of the terrorist organization "Islamic State", recruiting from the "periphery" of society the individuals easily persuaded to act on its behalf. [1] Its success is due to the social networks that offer a great potential in recruiting a large number of potential recruits, but to demonstrate this phenomenon, the author comes up with his own detailed vision, 
consisting of five parts: identification, creation of micro-communities, isolation, exchange of information and private communication, and the action to identify and encouragement. [2]

Following similar ideas, there should be mentioned the research of L. Mayevskaya, who expressed the same view on the impact of social media on the recruiting process. However, the author brings some conclusions drawn in studies of several researchers, such as R. Suleymanov, who noted that for a skilled propagandist and recruiter itis sometimes enough just his personal page. As example there have been made the pages of militants from Syria, when they, in detail, exposed and posted the footage of the fighting in the area. [19, p. 101] Another quoted author, A. Kabil, in her article also points out that the social networks are an effective weapon to recruit supporters for ISIS, recruiters in this group drawing attention to issues that cause disputes and debates. As the author noted, the mechanism of recruitment is quite simple, after posting a video with an act of mass execution and other atrocities, they are waiting for the comments on this video, and soon get in touch with those who have left comments, transmitting distorted information regarding what is happening in Syria. [19, p. 101]

It would be important to mention the large number of pages and communities that operate in order to "supplement" the rows of illegal armed groups and their accomplices, caused by an active propaganda activity of distributing informational materials aimed at inciting to national and religious intolerance. In addition, the Internet has made possible to coordinate the interaction between terrorist organizations remotely, anonymously and in trans-borders format, by hiding effectively the proofs of illegal activities. [21, p. 203]

In this regard, L. Mayevskaya emphasized that the recruiters do not aspire to reach Syria, their mission being to remain away to attract more militants to fight for the organization "Islamic State" and to bring many examples about these networks and "legends", that continues to attract new supporters through the virtual communities after proclaiming the "caliphate" on 29 June 2014. This situation put the matter before ISIS to spread its ideology to another level by extending its forms, and by the communication on Internet, the personal contact is avoided. For example, the recruiting of militants in Russian Federation, but not only there, could be simply made from abroad. In the paper, the author has focused on attracting through social networks of the divorced women and girls, making them promises to marry according Islamic traditions. The researcher stressed an important point regarding the contradictory opinions of caliphate supporters, expressing a disagreement about ideological visions of the terrorist organization "Islamic State". [19, p. 102]

As a classic example for recruitment through the Internet and social networks, most often is given the case of V. Karaulova, examined in clinical psychology as Varvara Karaulova syndrome. K. Fedorova states that it is already recognized that the social networking is one of the most effective recruitment tools in support of ISIS. [23, p. 132]

Referring to identifying the logic and ways of recruiters' operations within the ISIS group, M. Musaev and I. Abdulaev have proposed to determine the factors which could result in such a terrorist organization, when a person with a decent behaviour and suitable character, finally the authors coming up with some recommendations to prevent and fight against this phenomenon. [20, p. 52]

Switching from the private communication to the statement of the information exchange on social networks could be a signal to the law enforcement or supervisory, where the context is clearly appropriate (e.g., in response to a question about ISIS or somebody has several connections with 
Syria). Such measures should be focused on the most rational recruiters than their targets. Yet, the investigation demonstrates that the recruiters call to action appears to be a successful one, to the criminal liability is drawn the potential recruits, too.

One of the virtues of the Internet and social networking is that they put the pursuit of human interactions in a relatively narrow frame, which allows the monitoring of interaction in "backstage" style and recognize the processes when they occur repeatedly. Proceeding from the above, we emphasize that not all the users of virtual networks that have challenged any subject or action with an extremist-terrorist content should be immediately punished and we do not advocate for banning social networks and Internet or removing them just because they could be accessed by people with some delinquent intentions. The essence of the problem actually lies in the fact that the appearance of anonymity and high degree of difficulty, practically impossibility, to punish the weaned citizens of all world countries to realize the consequences before committing an action and to assume obligations for their acts.

Regarding the combating of recruitment, N. Bolychev proposed six levels to combat the interest in attracting young people in terrorist organizations, stressing the fact that the members of terrorist organizations are actively using the Internet for disseminating the extremist materials, attracting new supporters to its ranks and coordinating the illegal activity. Also, an opportunity provides the social networks VKontakte, Odnoklassniki, Facebook [15, p. 203], other authors adding that Twitter, Instagram, Ask.FM, Friend, Quitter, Diaspora. [21, p. 185]

Thus, intelligence services should cooperate actively with local authorities, other agencies and bodies of law enforcement for effectively counterterrorist activities with youth involvement in terrorist organizations, conducted through the Internet. Creating a social and informational positive environment, consistently strengthening at the legislative level the mechanisms to ensure a proper education of youth could help to a significant reduction of the terrorist offenses, and to oppose an effective resistance in the recruitment of young people in terrorist organizations.

In appearance to counter the recruitment phenomenon through the social networks, the researcher L. Mayevskaya wrote that the "hybrid-war occurs at a much larger scale in human consciousness, and after that on the battlefields". [19, p. 102] Likewise, she expressed the view that those measures should be carried out by not only blocking and closing the extremist groups and platforms, but the use of social networks should become the platform to counter the terrorist propaganda and recruitment processes.

In order to counter the phenomenon of recruitment online, E. Saltman and M. Smith, proposed to develop the counter-propaganda means designed especially for Muslim women and to strengthen the critical perception of propaganda by youth on the example of recruitment methods applied by ISIS. The authors identified three levels of prevention activities aimed to young people aged between 14 and 25 years (depending on the target audience): ISIS supporters, interested young people and the rest of the youth. [10, p. 52-57]

In the same context, other authors have expressed their position regarding the countermeasures considering that the government censorship of the Internet in not enough. It is necessary to attract the NGOs, independent activists, institutions of civil society, the countering of ISIS requiring to be both coordinated and decentralized. [16, p. 90] The countermeasures must work vigorously on recruitment efforts, challenging of terrorist propaganda being carried out at every possible opportunity. 
Finally, we conclude that the Internet and the means of advanced information technologies have become used to promote and support the terrorism, particularly in terms of propaganda (including for the purpose of recruitment, radicalization and incitement to terrorism), training and financing, planning and execution of such acts. In addition, the focus is on the opportunities offered by the Internet to detect and prevent the terrorist acts, including the intelligence gathering and other activities to inform in advance and deter them and gather evidence for prosecution of such acts. The strategic communication can become an effective means to disrupt the process of radicalization, manifested by terrorist acts. A demonstrated understanding of the issues is important in engaging in a constructive dialogue with the potential recruits into terrorist activities to promote some alternative causes.

Therefore, while, theoretically, the official channels of international cooperation are vital, in practice, the informal channels remain equally important. Regardless of the cooperation methods, the high level of trust between national and international authorities is a key-element within an effective cooperation process. In addition to the cooperation under formal treaties or similar legal instruments, or the sub-regional initiatives, aimed at strengthening cooperation in law enforcement, are equally important. The states with common interests in security could conclude some collective agreements providing for the transfer of information and exchange of related intelligence informative papers. Proceeding from the above, we plead for the following recommendations:

1) the national and international legal regulation in terms of preventing and combating of the cyber terrorism by analysing the national and international normative acts in counteracting propaganda through the social networks and Internet;

2) the elaboration of certain appropriate strategies that would provide some effective tools to prevent and combat this kind of crime;

3) the monitoring of the social media by intelligence services, with respect to the fundamental human rights, social phenomena and events that could degrade in some internal conflicts or could lead to destabilization of the public order and the state security;

4) the cooperation and joint efforts of the state, civil society and citizens on the need to eradicate the propaganda of terrorism on social networks and on Internet, to eliminate the causes and conditions, and to eradicate the terrorist ideology, promoted by cartoons, music, popular video clips and computer games;

5) the continuous studying of the recruiting methods for young people through the social networks and Internet and development of the effective measures to prevent and combat the recruitment in the terrorist organizations.

\section{References}

[1] BERGER, J.M.: How terrorists recruit online (and how to stop it). https://www.brookings. edu/blog/markaz/2015/11/09/how-terrorists-recruit-online-and-how-to-stop-it/. (12.11.2016)

[2] BERGER, J.M.: Tailored online interventions: the Islamic State's recruitment strategy. https://www.ctc.usma.edu/posts/tailored-online-interventions-the-islamic-states-recruitmentstrategy. (12.11.2016) 
[3] BOCKSTETTE, C.: Terrorists exploit information technologies. Use of Strategic Communication Calls for United Response, in: Per CONCORDIAM, vol. 1, No. 3, 2010.

[4] CONWAY, M.: Terrorist 'Use' of the Internet and Fighting Back, in: Conference Cybersafety: Safety and Security in a Networked World: Balancing Cyber-Rights and Responsibilities, Oxford Internet Institute (OII), Oxford University, UK, 8-10 September, 2005. https://www.oii.ox.ac.uk/archive/downloads/research/cyber safety/papers/maura_con way.pdf. (12.11.2016)

[5] Countering the Use of the Internet for Terrorist Purposes — Legal and Technical Aspects. May 2011. http://www.un.org/en/terrorism/ctitf/pdfs/ctitf_interagency_wg_compendium_ legal_technical_aspects_web.pdf $(01.12 .2016)$

[6] DENNING, D.E.: Terror's web: how the Internet is transforming terrorism, in: Y. Jewkes, M. Yar (eds.) Handbook of Internet Crime, Willan Publishing, 2010. (.pdf of pre-publication version). http://hdl.handle.net/10945/37164.

[7] EU Council Framework Decision 2008/919/JHA of 28 November 2008 amending Framework Decision 2002/475/JHA on combating terrorism, 28.11.2008, 2008/919/JHA.

[8] European Commission, Expert Group on Violent Radicalisation, Radicalisation processes leading to acts of terrorism (2008). See: www.clingendael.nl/publications/2008/20080500 _cscp_report_vries.pdf. (12.11.2016)

[9] GERWEHR, S. and DALY, S.: Al-Qaida: terrorist selection and recruitment, in: D. Kamien (ed.), The McGraw-Hill Homeland Security Handbook, McGraw-Hill, New York, 2006.

[10] SALTMAN, E.M. and SMITH, M.: Till Martyrdom Do Us Part' Gender and the ISIS Phenomenon, Institute for Strategic Dialogue, London, 2015.

[11] THOMAS, T.L.: Al Qaeda and the Internet: The Danger of "Cyberplanning”, http://7.iwar.org.uk/cyberterror/resources/cyberplanning/thomas.pdf. (01.12.2016)

[12] TOROK, R.: ISIS and the Institution of Online Terrorist Recruitment. http://www.mei.edu/content/map/isis-and-institution-online-terrorist-recruitment. (12.11. 2016)

[13] WEIMANN, G.: Online terrorists prey on the vulnerable, YaleGlobal Online, 5 March 2008. See: http://yaleglobal.yale.edu/content/online-terrorists-prey-vulnerable. (12.11. 2016)

[14] БЕШУКОВА, 3. М.: Противодействие экстремизму в Интернете: международный, зарубежный и внутригосударственный аспекты, in: Библиотека криминалиста, 2013, № 6. (BESHUKOVA, Z.M., Counteraction of extremism in Internet: international, foreign and domestic aspects, in: Criminalist's Library Scientific Journal, 2013, No. 6).

[15] БОЛЫЧЕВ, Н.И.: Противодействие вовлечению молодежи в радикальные организации, осуществляемому с помощью сети интернет, in: Вестник Воронежского института МВД России, 2016, № 1. (BOLYCHEV, N.I., Counteraction of youth involvement in radical 
organizations, carried out by the internet, in: VESTNIK of Voronezh Institute of the Ministry of the Interior of Russia, 2016, No. 1).

[16] БЫКАДОРОВА, А.С., ЧУРИЛОВ, С.А. and ШАПОВАЛОВА, Е.В.: Экстремизация молодежной аудитории сети интернет, in: Казанский Педагогический Журнал, 2016, № 3. (BYKADOROVA, A., CHURILOV, S., SHAPOVALOVA E., The extremism of youth in Internet, in: Kazan Pedagogical Journal, 2016, No. 3).

[17] ВОЛОСЮК, П.В.: Экстремизм как современная угроза российскому обществу и государству, in: Гуманитарные и юридические исследования, 2014, № 4. (VOLOSYUK, P.V., Extremism as present-day menace to the Russian society and state, in: Humanities and Law Research Journal, 2014, No. 4).

[18] ГОЛЯНДИН, Н.П. and ГОРЯЧЕВ, А.В.: Мотивации вербовки в экстремистские и террористические организации, in: Вестник Краснодарского Университета МВД России, 2013, № 2. (GOLYANDIN, N.P., GORYACHEV, A.V., Motivation for recruitment in extremist and terrorist organizations, in: VESTNIK of Krasnodar University of the Ministry of the Interior of Russia, 2013, No. 2).

[19] МАЕВСКАЯ, Л.Б.: Социальные сети и методы вербовки сторонников ИГ, угроза национальной безопасности стран СНГ, in: Современные Евразийские Исследования, Научный журнал, 2015, Выпуск 4. (MAYEVSKAYA, L., Social networks and methods of recruitment of supporters of the IS, the threat to national security of the CIS countries, in: Contemporary Eurasian Studies, Academic journal, 2015, Issue 4).

[20] МУСАЕВ, М.М. and АБДУЛАЕВ, И.М.: Способы и методы психологического воздействия на сознание людей, используемые вербовщиками ИГИЛ для вовлечения в свои ряды новых сторонников, in: Международный Научно-Исследовательский Журнал „Успехи современной науки и образования”, 2016, №7. (MUSAEV, M.M., ABDULAEV, I.M, Techniques and methods of psychological influence on the minds of people used by ISIL recruiters for enlisting new supporters, in: Успехи современной науки и образования, 2016, No. 7).

[21] МУХАМЕТЗАРИПОВ, И.А.: Зарубежный опыт противодействия пропаганде ИГИЛ в среде «европейских» мусульман, in: Казанский Педагогический Журнал, 2016, № 3. (MUKHAMETZARIPOV, I., The foreign experience of counteraction to DAESH propaganda among the "European” Muslims, in: Kazan Pedagogical Journal, 2016, № 3).

[22] РАХМОНОВ, А.С.: Внешние и внутренние факторы вовлечения молодёжи в ряды террористических организаций, in: Казанский педагогический журнал, 2013, №6. (RAKHMONOV, A.S., External and internal factors of the youth involvement in the terrorist organizations, in: Kazan Pedagogical Journal, 2013, № 6).

[23] ФЁДОРОВА, К.В.: Вербовка как искусственное формирование поведенческой аддикции на примере синдрома Варвары Карауловой, in: Казанский педагогический журнал, 2016, №6. (FEDOROVA, K., Recruiting as an intentional formation of behavioral addiction (on the example of Varvara KARAULOVA syndrome), in: Kazan Pedagogical Journal, 2016, № 3). 


\title{
ICT IMPACT ON DEVELOPMENT OF KNOWLEDGE ECONOMY IN UKRAINE AND REPUBLIC OF MOLDOVA
}

\author{
Anastasia Stefanita ${ }^{1}$, Larysa Emelyanenko ${ }^{2}$ and Tetiana Shkoda ${ }^{3}$
}

\begin{abstract}
In this paper, the authors analysed the value of the development of information and communication technologies as an innovative resource of the knowledge economy. The analysis of the knowledge economy state of Ukraine and Republic of Moldovain the international dimension is conducted. The statistical analysis is based on macro data of the Global Innovation Index for the period 2012-2016 that limits the relevance of the results obtained. The practical examples of information and communication technologies used by public sector in the knowledge economy are described. It is proved the importance of information and communication technologies as a key component of the economic system based on knowledge.
\end{abstract}

The paper has the goal to underline the positive aspects of the knowledge economy in Ukraine and Republic of Moldova due to ICT tools but also to put into discussion the backlogs of the development processes in these countries.

\section{Introduction}

\subsection{The scope of the paper}

The knowledge economy is quite controversial phenomenon, as it puts innovation processes of different levels at the centre of the economic system. And the world competitiveness of any country is closely connected with the state of the development of the knowledge economy.

Transformation processes in Ukraine and Republic of Moldova connected with their European integration intentions require a deep reload of both their economic systems and public management. As both countries represent post-soviet states, it is interesting to compare the state of their knowledge economies development in general and the level of implementing information and communication technologies as an innovative resource of the knowledge economy at the example of public sector.

\subsection{General notes on knowledge economy}

Accelerated innovative transformation of the modern economy shows the increasing importance of knowledge as a decisive factor in innovation and technological development. Under the new conditions other basics of the globally competitive national economy, except in the form of a

\footnotetext{
1 Information Society Development Institute, 5A Academiei Str., Chisinau, MD-2028, Republic of Moldova, anastasia.stefanita@idsi.md

${ }^{2}$ Kyiv National Economic University named after Vadym Hetman, 54/1 Peremogy Prospect, Kyiv, 03680, Ukraine, larysa.yemelianenko@kneu.ua

${ }^{3}$ Kyiv National Economic University named after Vadym Hetman, 54/1 Peremogy Prospect, Kyiv, 03680, Ukraine, tetiana.shkoda@kneu.ua
} 
"knowledge economy" does not exist. This trend changes the configuration of the mechanism of economic growth [27].

The knowledge economy is defined as a special innovative model of production in the form of complementary information and communication technologies, human capital (using these technologies) and the creative potential of firms (implementing productivity of the first two elements) on the background of social networks, which will replace the traditional forms of organization of the market in the knowledge economy [2].

Deepening economic diversification, the predominance of a knowledge-based and high-tech products in the structure of GDP, the dominance of networking interaction of economic agents are the hallmarks of the knowledge economy's growth [7; 9].

Conceptual interpretation of the "knowledge economy" as a special production method understands it as a system, in which the processes of generation, application and dissemination of knowledge play a dominant role in the creation of tangible, material and intellectual wealth, as well as generally accepted social values.

In the public sector the knowledge economy has its own specifics. It requires the utilization of the knowledge in order to improve the transparence, the services delivering to the citizens, for a better communication with the citizens/users/clients and in order to improve the knowing degree of their needs [14].

\section{Knowledge economy state of Ukraine and Republic of Moldova}

Development of knowledge economy is defined by modern economic theory and practice of effective public and business activities as a key factor of the sustainable economic development. According to Mahfouz E. Tadros [20] knowledge-based development requires strong R\&D institutions, an industrial base, a pool of skills and competences, a strong physical and cyber infrastructure, and a business-friendly regulatory framework.

One of the strategic directions of development for Ukraine is modernization of its social and economic system on the base of implementing new technologies and innovations in all spheres of human activity, synchronization of the development of nature, economy and human [4]. Such modernization is also important for Moldova. Moreover, a big emphasis in Moldova is on IT development, that started from the government level (since 2011 through Governance eTransformation Program and Project with the World Bank support) and besides public processes is oriented as well to citizens and business.

Nowadays various frameworks and methodologies are used for assessing the development of knowledge economy of countries. These instruments are developed by such organizations as World Bank Institute [30], the Organization for Economic Cooperation and Development (OECD) [13], the European Union institutions [11], World Economic Forum [31] and the World Intellectual Property Organization in collaboration with Cornell University, INSEAD [25].

As the aim of our paper is to show the value of the development of information and communication technologies as an innovative resource of the knowledge economy, in our research we used the Global Innovation Index (GII) data for the period 2012-2016. It also helped us to present the analysis of the knowledge economy state of Ukraine and Republic of Moldova in the 
international dimension as GII is used as one of the main world indicators of the knowledge economy's state.

In general, according to the GII Report 2015 [24] the Innovation Input Sub-Index consists of five input pillars that capture the national economy elements that enable innovative activities and reflects the innovative character of the country's knowledge economy: (1) Institutions, (2) Human capital and research, (3) Infrastructure, (4) Market sophistication, and (5) Business sophistication. On the other hand, the Innovation Output Sub-Index is comprise of two output pillars that are the results of innovative activities within the economy: (6) Knowledge and technology outputs, (7) Creative outputs.

\subsection{Ukraine situation}

The analysis for Ukraine as a representative of the lower-middle-income countries in GII 2015 shows that from 2014 it remains in the top 10 countries of this group.

Ukraine outperformed its peers in at least four innovation input or output pillars of GII during 20112014 (Table 1). It is also positioned as an innovative achiever, but not improved its total GII ranking during 2014-2015. Ukraine demonstrates rising levels of innovation results because it has a skilled labor force with expanded tertiary education. In 2016 Ukraine takes $40^{\text {th }}$ position among the investigated countries in GII 2016 Report, but it has lost 4 positions in comparison with 2015 year. Despite this fact the result for (2) Human capital \& research in 2016 (40 $0^{\text {th }}$ place) is higher than in $2012\left(48^{\text {th }}\right.$ place $)$.

\begin{tabular}{|l|c|c|c|c|c|c|c|c|c|}
\hline Index & 2012 & $\begin{array}{c}\Delta 2013- \\
2012\end{array}$ & 2013 & $\begin{array}{c}\Delta 2014- \\
2013\end{array}$ & 2014 & $\begin{array}{c}\Delta 2015- \\
2014\end{array}$ & 2015 & $\begin{array}{c}\Delta 2016- \\
2015\end{array}$ & 2016 \\
\hline GII & 63 & $8 \downarrow$ & 71 & $8 \uparrow$ & 63 & $1 \downarrow$ & 64 & $8 \uparrow$ & 56 \\
\hline 1. Institutions & 117 & $12 \uparrow$ & 105 & $2 \uparrow$ & 103 & $5 \uparrow$ & 98 & $3 \downarrow$ & 101 \\
\hline $\begin{array}{l}\text { 2. Human } \\
\text { capital \& } \\
\text { research }\end{array}$ & 48 & $4 \uparrow$ & 44 & $1 \downarrow$ & 45 & $9 \uparrow$ & 36 & $4 \downarrow$ & 40 \\
\hline 3. Infrastructure & 98 & $7 \uparrow$ & 91 & $16 \downarrow$ & 107 & $5 \downarrow$ & 112 & $13 \uparrow$ & 99 \\
\hline $\begin{array}{l}\text { 4. Market } \\
\text { sophistication }\end{array}$ & 68 & $14 \downarrow$ & 82 & $8 \downarrow$ & 90 & $1 \uparrow$ & 89 & $14 \uparrow$ & 75 \\
\hline $\begin{array}{l}\text { 5. Business } \\
\text { sophistication }\end{array}$ & 51 & $28 \downarrow$ & 79 & $8 \downarrow$ & 87 & $9 \uparrow$ & 78 & $5 \uparrow$ & 73 \\
\hline $\begin{array}{l}\text { 6. Knowledge \& } \\
\text { technology } \\
\text { outputs }\end{array}$ & 30 & $15 \downarrow$ & 45 & $13 \uparrow$ & 32 & $2 \downarrow$ & 34 & $1 \uparrow$ & 33 \\
\hline $\begin{array}{l}\text { 7. Creative } \\
\text { outputs }\end{array}$ & 83 & $2 \uparrow$ & 81 & $4 \uparrow$ & 77 & $2 \uparrow$ & 75 & $17 \uparrow$ & 58 \\
\hline
\end{tabular}

Table 1: GII for Ukraine

Source: composed and calculated by the authors on the basis of $[21 ; 22 ; 23 ; 24 ; 25]$

The country demonstrates the lowest results by such indicators as Institutions and Infrastructure among other innovative inputs. Despite this fact, there is a conventionally positive dynamics for $2012-2016$ by theses indicators. For example, $117^{\text {th }}$ place $(2012), 103^{\text {rd }}$ place $(2014)$ and $101^{\text {st }}$ place 
(2016) of Ukraine by (1) Institutions show that the country isn't attractive very much for businesses and doesn't provide good governance and the correct levels of protection and incentives that are essential to innovation.

At the same time there is some negative dynamics for (4) Market sophistication and (5) Business sophistication, especially in 2012-2014. There is a statement in the concept of reform of government policy in the field of innovations approved by Resolution of the Cabinet of Ministers of Ukraine (CMU) no. 691 of 10.09.2012 that the majority of businesses are technologically backward and energy-intensive. It is connected with bad market conditions and a lack of credit investments for innovations development. And it also demonstrates the failure of the state innovation policy of Ukraine and its principle of independent innovation development.

It is visible that there is a gap between such pillar as (2) Human capital \& research and all other elements of GII for Ukraine.

By innovative outputs Ukraine takes good position in GII ranking. In 2016 it has $33^{\text {rd }}$ place by (6) Knowledge \& technology outputs and $58^{\text {th }}$ place by (7) Creative outputs. Comparing the country's positions for the 2012-2016 periods by these indicators, the authors should admit that Ukraine has saved the average results for (6) Knowledge \& technology, but it has also improved its results by (7) Creative outputs for the same period of time ( $83^{\text {rd }}$ place in 2012 and $58^{\text {th }}$ place in 2016).

To improve its innovativeness and competitiveness on the way of transformation to the knowledge economy in 2013 CMU adopted the Strategy of information society development in Ukraine by Resolution no. 386-p of 15.05.2013. To realise this strategy in 2015 Ukraine joined Horizon 2020 to work with EU in science and research. The agreement was ratified by the Ukrainian Parliament and entered into force. According to it Ukrainian legal entities can participate in all Horizon 2020 actions funded under the 2015 budget, as this association covers the years 2015-2020 [5].

\subsection{Republic of Moldova situation}

According to the Global Innovation Index Report from 2015, the Republic of Moldova is one of the eleven developing countries that are labelled 'innovation outperformers' because they conform to the following two more stringent rules:

- $\quad$ their GII score relative to their GDP is significantly higher than it is for other economies (they attain 'innovation achiever' status) for two or more recent years (including at least 2013 and 2014);

- $\quad$ they outperform their income-group peers in a minimum of four innovation input or output pillars (they are designated 'pillar outperformers') for two or more years (including at least 2013 and 2014).

On average, the technology gap between developing and developed countries appears to be narrowing. One explanation is that more and more developing countries outperform in innovation inputs and outputs relative to their level of development (Moldova's case). Among other developing countries, Moldova have realized that technology adoption alone is no longer sufficient to maintain a high-growth scenario; rather innovation is now crucial for catching up to high-income countries. As a result, national innovation policy programmes are flourishing in low- and middle-income countries. The Republic of Moldova has been identified as one of the rising innovators in Europe. 
Its performance has been consistent in almost all innovation inputs and outputs during 2011-14 (Table 2). It performed above $75 \%$ of the economies in the GII in Knowledge and technology outputs and Creative outputs. These high scores are the result of high numbers of utility model applications and trademark registrations. Indeed, government efforts towards increasing intellectual property rights awareness and encouraging its use led to the establishment of the State Agency on Intellectual Property and the implementation of a National Intellectual Property Strategy, which have been in place since 2011 and 2012, respectively. These efforts may at least partially explain the country's high scores in these indicators. The Republic of Moldova performs poorly in Business sophistication, however, because of weak innovation linkages — in particular its limited cluster development and university-industry collaborations [24].

\begin{tabular}{|l|c|c|c|c|c|c|c|c|c|}
\hline \multicolumn{1}{|c|}{ Index } & $\mathbf{2 0 1 2}$ & $\begin{array}{c}\Delta \mathbf{2 0 1 3}- \\
\mathbf{2 0 1 2}\end{array}$ & $\mathbf{2 0 1 3}$ & $\begin{array}{c}\Delta \mathbf{2 0 1 4} \\
\mathbf{2 0 1 3}\end{array}$ & $\mathbf{2 0 1 4}$ & $\begin{array}{c}\Delta \mathbf{2 0 1 5} \\
\mathbf{2 0 1 4}\end{array}$ & $\mathbf{2 0 1 5}$ & $\begin{array}{c}\Delta \mathbf{2 0 1 6} \\
\mathbf{2 0 1 5}\end{array}$ & $\mathbf{2 0 1 6}$ \\
\hline GII & 50 & $5 \uparrow$ & 45 & $2 \uparrow$ & 43 & $1 \downarrow$ & 44 & $\mathbf{2} \downarrow$ & 46 \\
\hline 1. Institutions & 78 & $6 \downarrow$ & 84 & $4 \uparrow$ & 80 & $5 \uparrow$ & 75 & $\mathbf{7 \uparrow}$ & 68 \\
\hline $\begin{array}{l}\text { 2. Human } \\
\text { capital \& } \\
\text { research }\end{array}$ & 55 & $6 \uparrow$ & 49 & $22 \downarrow$ & 71 & $3 \downarrow$ & 74 & $\mathbf{2 3 \uparrow}$ & 51 \\
\hline 3. Infrastructure & 85 & $4 \uparrow$ & 81 & $7 \downarrow$ & 88 & $6 \uparrow$ & 82 & $\mathbf{7 \uparrow}$ & 75 \\
\hline $\begin{array}{l}\text { 4. Market } \\
\text { sophistication }\end{array}$ & 96 & $17 \uparrow$ & 79 & $30 \uparrow$ & 49 & $3 \downarrow$ & 52 & $\mathbf{4 1} \downarrow$ & 93 \\
\hline $\begin{array}{l}\text { 5. Business } \\
\text { sophistication }\end{array}$ & 104 & $19 \uparrow$ & 85 & $17 \downarrow$ & 102 & $19 \uparrow$ & 83 & $\mathbf{6} \downarrow$ & 89 \\
\hline $\begin{array}{l}\text { 6. Knowledge \& } \\
\text { technology } \\
\text { outputs }\end{array}$ & 31 & $5 \uparrow$ & 26 & $0 \leftrightarrow$ & 26 & $0 \leftrightarrow$ & 26 & $\mathbf{5} \downarrow$ & 31 \\
\hline $\begin{array}{l}\text { 7. Creative } \\
\text { outputs }\end{array}$ & 32 & $0 \leftrightarrow$ & 32 & $0 \leftrightarrow$ & 32 & $6 \downarrow$ & 38 & $\mathbf{4} \uparrow$ & 34 \\
\hline
\end{tabular}

Table 2: GII for Moldova

Source: composed and calculated by the authors on the basis of $[21 ; 22 ; 23 ; 24 ; 25]$

The Republic of Moldova introduced its innovation strategy 'Innovations for Competitiveness' for the period 2013-2020. This strategy aims to stimulate innovation in firms and society in general. In the same context, the Strategy for Research and Development of the Republic of Moldova until 2020 was drafted under the guidance of the Academy of Sciences of Moldova and approved by the Government in December 2013, aiming at increasing investments in research and development to $1 \%$ of GDP by 2020 . None of the strategies clearly identifies thematic priorities (for example, in the Research and Development Strategy the six societal challenges of Horizon 2020 are mentioned as priorities). During last months of 2016 several decisions were taken referring to Government reform through restructuring the ministries and other central institutions, including research and development \& innovation sector. In this respect would follow several mergers, transfer of responsibilities and other institutional and functional changes.

The number of persons employed in Research \& Development sector in Moldova decreased significantly due to "brain drain", while among the remaining researchers a certain ageing trend can be observed. At the same time, the R\&D field is unattractive (from salary and existing infrastructure points of view) for young talents. The level of knowledge obtained in local universities does not meet market expectations, while attraction of foreign students or researchers is difficult due to unappealing conditions [1]. 
Both Ukraine and Republic of Moldova belong to the 14 middle-income countries outperforming others in their income group [24]. But, in general, Republic of Moldova takes stronger positions in different components of GII than Ukraine. It happens because of more successful government policy in different spheres of knowledge economy.

\section{ICT tools used by public sector in the knowledge economy}

Information and communication technologies (ICT) provide almost unlimited possibilities of doing business, scientific and research, artistic and other activities in the Internet, and they allow citizens to participate in forming the policy of developing society, economy and education. ICT, which provided the basis for the knowledge economy, continue to develop and offer the possibility of using new approaches to social and economic development [29]. For example, it is done by involving citizens into the innovation activity. The greatest attention should be paid to communication channels and means of communication and exchange of information between citizens (consumers), manufacturers and governments to use the intellectual potential of society [16].

Currently, a set of ICT goes into a new quality of the interaction with public authorities and private companies. Modern citizens have an opportunity to participate in the discussion of public decisions and influence the formation of national and municipal policies by e-government tools. The use of ICT in the economy allows companies to reach new economic effects by adapting to the everchanging business environment, the creation of mobile offices, continuous communication with partners and customers.

A new type of communication between citizens, producers and governments via ensuring the free exchange of information is one of the main advantages of the knowledge economy [18].

Key changes occur in the field of mass interaction of public authorities with citizens in the following areas: development of electronic interagency cooperation; providing services in electronic form; development of portals and provision of information on the activities of public authorities; implementation of a universal electronic citizen card. They form the primary basis, the foundation of the "electronic government"; provide a transition of traditional bureaucratic functions in the Internet space. In each of these areas, the government makes great efforts: creates and adapts the regulatory framework, develops and distributes software solutions, conducts constant coordination with the regions and municipalities, sets the pace of development, overcomes resistance, allocates huge resources, etc.

The dynamics of ICT development in public sector of the analysed countries is presented in Table 3 and Table 4. These tables consist of the indicators that are the part of (3) Infrastructure pillar of the Innovation Input Sub-Index of the GII. The basic results are gathered and calculated by the World Intellectual Property Organization in collaboration with Cornell University, INSEAD [21; 22; 23; 24; 25]. The authors composed the data of the tables based on Ukraine and Moldova countries' profiles and then calculated the changes by years. 


\begin{tabular}{|l|c|c|c|c|c|c|c|c|c|}
\hline \multicolumn{1}{|c|}{ Index } & $\mathbf{2 0 1 2}$ & $\begin{array}{c}\Delta \mathbf{2 0 1 3 -} \\
\mathbf{2 0 1 2}\end{array}$ & $\mathbf{2 0 1 3}$ & $\begin{array}{c}\Delta \mathbf{2 0 1 4 -} \\
\mathbf{2 0 1 3}\end{array}$ & $\mathbf{2 0 1 4}$ & $\begin{array}{c}\Delta \mathbf{2 0 1 5} \\
\mathbf{2 0 1 4}\end{array}$ & $\mathbf{2 0 1 5}$ & $\begin{array}{c}\Delta \text { 2016- } \\
\mathbf{2 0 1 5}\end{array}$ & $\mathbf{2 0 1 6}$ \\
\hline ICTs & 77 & $2 \downarrow$ & 79 & $5 \downarrow$ & 84 & $5 \downarrow$ & 89 & $2 \uparrow$ & 87 \\
\hline ICT access & 58 & $8 \downarrow$ & 66 & $2 \uparrow$ & 64 & $1 \uparrow$ & 63 & $1 \uparrow$ & 62 \\
\hline ICT use & 81 & $15 \uparrow$ & 66 & $21 \downarrow$ & 87 & $2 \downarrow$ & 89 & $3 \downarrow$ & 92 \\
\hline $\begin{array}{l}\text { Government's } \\
\text { online service }\end{array}$ & 88 & $1 \downarrow$ & 89 & $1 \downarrow$ & 90 & $22 \downarrow$ & 112 & $7 \uparrow$ & 105 \\
\hline E-participation & 78 & $1 \downarrow$ & 79 & $0 \leftrightarrow$ & 79 & $3 \uparrow$ & 76 & $2 \uparrow$ & 74 \\
\hline
\end{tabular}

Table 3: ICTs for Ukraine

Source: composed and calculated by the authors on the basis of $[21 ; 22 ; 23 ; 24 ; 25]$

Ukraine is not among the leaders in the world by ICT (Table 3). In 2016 the country takes only $87^{\text {th }}$ place. It could be explained by the fact that several important legislative reforms such as the Law on Citizens' Petitions (2015), Law on Access to Public Information and Open Data (2015) and the Law on the Open Use of Public Funds were passed in Ukraine.

Government's online service, especially the e-declaration system as its key part, is the most discussed topic in Ukraine during 2016. Now everyone has access to the information about assets and revenues of officials as foreseen by the law № 1022-VIII adopted by the Verkhovna Rada on 15 of March this year [10].

The development of e-governance in Ukraine is also one of the main goals of the EU and Council of Europe joint programme „Strengthening Information Society in Ukraine“ [3]. This program aims at improving the freedom, diversity and pluralism of the media and strengthening personal data protection.

E-governance in Ukraine is only in its infancy. The country has all the necessary technical equipment to establish a functional system of electronic governance. The main challenge is the insufficient digital literacy of citizens and civil servants [6].

A recent national OMNIBUS public opinion survey showed ordinary Ukrainian citizens are not very aware of the possible benefits of e-government and e-democracy initiatives: $86 \%$ did not understand what e-government means, $79 \%$ have never heard of the term e-democracy and only $41 \%$ thought that they may have some idea of the term's meaning [26].

Ukraine should use its IT as a socio-economic driver for the knowledge economy transformation. Ukraine's 402 universities and colleges annually produce more science graduates than many reputable hi-tech countries in Asia and Western Europe. Ukraine's 90,000 IT professionals is the largest professional IT community in Europe with the numbers expected to rise to over 200,000 in 2020 [26]. So, Ukrainian government just should use this resource in the appropriate way.

Republic of Moldova has better situation with ICT development than Ukraine. The current ICT market in Moldova is primarily in a buildout phase, with major investments focused on basic hardware infrastructure, such as server, storage, infrastructure software, and network equipment implementations. In 2016 Moldova takes $51^{\text {st }}$ position by the ICT indicator in GII Report (Table 4).

Moldova has one of the best-wired Internet connections in the world as well as one of the cheapest in terms of price per Mbit. The overall infrastructure is well developed which allows many users to 
experience good quality services throughout the country. However, despite high speeds and cheap prices, the penetration level is quite low when compared with many EU or CIS countries [12].

\begin{tabular}{|l|c|c|c|c|c|c|c|c|c|}
\hline \multicolumn{1}{|c|}{ Index } & $\mathbf{2 0 1 2}$ & $\begin{array}{c}\Delta \mathbf{2 0 1 3 -} \\
\mathbf{2 0 1 2}\end{array}$ & $\mathbf{2 0 1 3}$ & $\begin{array}{c}\Delta \mathbf{2 0 1 4 -} \\
\mathbf{2 0 1 3}\end{array}$ & $\mathbf{2 0 1 4}$ & $\begin{array}{c}\Delta \mathbf{2 0 1 5} \\
\mathbf{2 0 1 4}\end{array}$ & $\mathbf{2 0 1 5}$ & $\begin{array}{c}\Delta \mathbf{2 0 1 6 -} \\
\mathbf{2 0 1 5}\end{array}$ & $\mathbf{2 0 1 6}$ \\
\hline ICTs & 56 & $6 \uparrow$ & 50 & $8 \downarrow$ & 58 & $10 \uparrow$ & 48 & $3 \downarrow$ & 51 \\
\hline ICT access & 55 & $1 \uparrow$ & 54 & $1 \downarrow$ & 55 & $0 \leftrightarrow$ & 55 & $2 \uparrow$ & 53 \\
\hline ICT use & 57 & $2 \uparrow$ & 55 & $19 \downarrow$ & 74 & $17 \uparrow$ & 57 & $4 \downarrow$ & 61 \\
\hline $\begin{array}{l}\text { Government's } \\
\text { online service }\end{array}$ & 61 & $0 \leftrightarrow$ & 61 & $1 \downarrow$ & 62 & $3 \downarrow$ & 65 & $5 \uparrow$ & 60 \\
\hline E-participation & 38 & $0 \leftrightarrow$ & 38 & $0 \leftrightarrow$ & 38 & $2 \uparrow$ & 40 & $0 \leftrightarrow$ & 40 \\
\hline
\end{tabular}

Table 4: ICTs for Moldova

Source: composed and calculated by the authors on the basis of $[21 ; 22 ; 23 ; 24 ; 25]$

The Republic of Moldova achieved significant progress in the implementation of information society technologies, ICT contribution share to GDP in recent years has reached the level of almost $8-10 \%$, every second citizen is an Internet user, more than half of households have at least one computer, the majority of connected households have access to broadband Internet, the biometric passport, the ID card with electronic signature, the e-Statements system and digital map were implemented, country joined the "Open Government Data" initiative, etc. However, in international classifications the country is not placed among the advanced economies in this field, and the level and speed of information society development do not meet the current international environment requirements, in which the world is becoming even more "hyperconnected" and more digitized [8].

The regulatory framework in ICT field is more or less functional and partial harmonised with European norms. The Government of the Republic of Moldova has recognized the need to use ICT as a crosscutting enabler of sustainable growth, competitiveness and improved governance, and in this context, it has requested the World Bank's assistance to enable the e-transformation of Moldova. The Governance e-Transformation Project is designed to increase efficiency and quality of a selected range of public services to citizens and businesses and improve management of ICT in the public sector [17]. E-Transformation Strategy (from 2011) is a logical continuation of actions undertaken beginning with 1990 (when was started the institutional framework) and 1993 (start of the legal and methodological framework development) and later 2005 when was implemented the National Strategy for Information Society Action Plan „Electronic Moldova”.

Among other initiatives, within e-Transformation project a unique platform (servicii.gov.md) for public services provided by the authorities was launched in 2012. The servicii.gov.md platform functions as an electronic catalogue for public services provided by the authorities dedicated to citizens and the business environment. The main purpose of this platform is to offer brief, correct, accessible and complete information on the public services available in the Republic of Moldova. On the platform, can be found information regarding both electronic services, as well as traditional services. Currently, there are 566 services on the portal, of which 125 are e-Services (on-line services) with data opened for access [15]. The Republic of Moldova Government is determined to transform all traditional counter services into e-services by 2020, through the „Open Government action plan" and the „Government technological modernisation strategy”. In this way, the citizens will be able to access over 500 e-services. 
Referring to e-participation the Moldavian government launched in 2012 the "particip.gov.md" platform. Through this platform citizens can be consulted on various draft laws. Until now almost 2500 drafts of Government Decisions, 775 Law drafts, 170 strategies, 115 Regulations and 300 other draft policies were published for large consultation on the platform.

Talking about IT tools in public sector, it should be mentioned the pilot-project Management System of Documents and Authorities Registrations (SIGEDIA) that is part of the Action Plan for the initiative implementation "Paperless Government" in Moldova, approved through Government Decision no. 262 from 15.04.2013. Through SIGEDIA, the electronic circulation of the documents inside the Government is much more reliable, the system replacing the huge amount of paper that was being used in the executive with electronic documents. The electronic documents used by the ministries have the same juridical power as the ones on paper. Another provision of this project requires clerks to use professional email addresses (gov), so that the use of multiple public communication platforms would be eliminated. The system "sigedia.gov.md" was implemented in the State Chancellery and 7 ministries [19].

The rise in demand for exports in manufacturing, the growing usage of IT in the finance sector, transformations in the telecommunications industry, and demand in the government sector will fuel IT services market growth. Since the public sector (government administration, defence, police, judiciary, healthcare, education, and state-owned public enterprises) accounts for the bulk of IT spending in Moldova, it is crucial for IT vendors to be proactive in their dealings with this vertical market. This means educating policymakers and civil servants in decision-making positions in particular, conducting marketing studies and benchmarking, and organizing conferences, as well as offering attractive financial arrangements, outsourcing, and more. Current and future investments in Government IT will represent the main driving force in the Moldovan IT Services market in the near future [28].

\section{Conclusions}

In the long term, the IT services market of Moldova is expected to be driven primarily by large government projects, such as new e-government initiatives and technology investments in highly competitive sectors (e.g., banking and telecommunications) and initiatives that support the alignment of IT with business goals. The Moldovan government is expected to continue to upgrade public infrastructure, and remain committed to e-government initiatives aimed at improving the quality of public services [28] countrywide.

Ukraine has less developed ICT sphere than Republic of Moldova. Ukraine has the potential to do much more in modernizing its public administration system and in utilizing domestic human capital in the ICT sphere. Ukrainian government should change its attitude to the country's human capital as a resource to export, but has to consider the ICT sphere's human capital also as a key resource to strengthen the public sector of the state.

\section{References}

[1] Academy of Sciences of Moldova. The Knowledge Triangle in Moldova. Chisinau, 2016. Available at: http://www.ase.md/files/proiecte/fktbum.pdf accessed on 14.12.2016

[2] BAZHAL IU, M.: Knowledge economy: theory and public policy (Znannieva ekonomika: teoria i derzhavna polityka). Ekonomika i prognozuvannia $2003 \mathrm{Nr} 3$, pp. 71-86. 
[3] Council of Europe Office in Ukraine. Strengthening Information Society in Ukraine. Available at: http://www.coe. int/en/web/kyiv/41 accessed on 27.12.2016.

[4] Emelyanenko L. M.. Synergetic approach in the methodology of managing the economic development of Ukraine (Synergetychnyj pidkhid v metodologii upravlinnia ekonomichnym rozvytkom Ukrainy). Visnyk Lvivskogo universytetu. Seria ekonomichna. Issue 51, 2014, pp. $32-40$.

[5] European Commission: Ukraine joins Horizon 2020 to work with EU in science and research, 2015. Available at: http://europa.eu/rapid/press-release_IP-15-4640_en.htm accessed on 27.12.2016.

[6] EU in Ukraine: E-governance in Ukraine: challenges and opportunities, Cooperation News, 2015. Available at: https://euukrainecoop.com/2015/06/02/e-gov/ accessed on 28.12.2016.

[7] FEDULOVA, L. I. and Kotneeva, T. M.: Features of the knowledge economy in the modern phase of development of society. Theory and practice of building in Ukraine. (Osoblyvosti ekonomiky znan na suchasnij fazi rozvytku suspilstva. Teoria i praktyka rozbudovy v Ukraini.). Aktualni problem ekonomiky i praktyky. Nr 4, Vol. 106, 2010, pp. 74-86.

[8] Government of the Republic of Moldova: National Strategy for the development of information society „Digital Moldova 2020”, Decision no. 857 from 31.10.2013. Available at: http://www.mtic.gov.md/sites/default/files/transparency/public_consults/hg_857_31_10_2013 _nationalstrategymoldovadigitala2020en.pdf accessed on 14.12.2016.

[9] HEYETS, V. M.: Character of transition processes to knowledge economy (Kharakter perehidnykh protsesiv do ekonomiky znan). Ekonomika Ukrainy, $2004 \mathrm{Nr} 4$, pp. 4-14; Nr 5, pp. 4-13.

[10] HIEMSTRA, J.: E-declaration is a real breakthrough in Ukrainian reforms, 2016. Available at: http://www.ua.undp.org/content/ukraine/en/home/ourperspective/ourperspectivearticles/ 2016/10/31/e-declaration-is-a-real-breakthrough-in-ukrainian-reforms.html accessed on 28.12.2016.

[11] Innovation Union Scoreboard (IUS): The Innovation Union's performance scoreboard for Research and Innovation, 2010. Available at: https://ec.europa.eu/research/innovationunion/pdf/iu-scoreboard-2010_en.pdf accessed on 10.12.2016.

[12] Internet in Moldova. Wikipedia. Available at: https://en.wikipedia.org/wiki/Internet_in_ Moldova accessed on 14.12.2016.

[13] Organization for Economic Cooperation and Development (OECD): OECD Science, Technology and Industry Scoreboard, 2005. Available at: http:/www.oecdlibrary.org/docserver/download/9205071e.pdf?expires=1481630258\&id=id\&accname=guest \&checksum=57B44E4958023D428F1BC2E0215BD7C4 accessed on 10.12.2016

[14] PĂCEŞILĂ, M: The impact of moving to knowledge based economy in the public sector, 2006. Available at: http://www.mnmk.ro/documents/2006/2006-14.pdf accessed on 28.12.2016. 
[15] Public services platform of Moldova. Available at: https://servicii.gov.md/ accessed on 14.12.2016.

[16] RABOTA YU, I.: Public Relations as Public Administration Institute (Zv'jazky z gromadskistiu jak instytut derzhavnogo upravlinnia) : $\mathrm{PhD}$ Thesis on public management. Kharkiv, 2006, p. 20.

[17] Report on e-Transformation project 2015, Moldova. Available at: http://www.egov.md/en/ transparency/reports/governance-e-transformation-project-moldova-report-period-2013-2015 accessed on 20.12.2016.

[18] SIBIRIAKOV, S.: Communication practices in public management in context of the information society development (Komunikatyvni praktyky u derzhavnomu upravlinni v konteksti rozvytku informatsijnogo suspilstva), Derzhavne upravlinnia, 2010. Available at: http://www.nbuv.gov.ua/portal/soc_gum/Pubupr/2010/2010-34/doc/1/16.pdf

[19] SIGEDIA - electronic document management system for Central Public Administration of Moldova.. Available at: http://www.egov.md/en/projects/sigedia accessed on 20.12.2016.

[20] TADROS, M.E.: The Arab Gulf States and the Knowledge Economy: Challenges and Opportunities, 2015. Available at: http://www.agsiw.org/wp-content/uploads/2015/07/ Tadros_Knowledge-Economy_Rev1.pdf accessed on 24.12.2016.

[21] The Global Innovation Index 2012, Stronger Innovation Linkages for Global Growth. Available at: https://www. global innovationindex. org/userfiles/file/gii-2012-report.pdf accessed on 12.12.2016.

[22] The Global Innovation Index 2013. The Local Dynamics of Innovation. Available at: http://www.wipo.int/edocs/ pubdocs/en/economics/gii/gii_2013.pdf accessed on 12.12.2016.

[23] The Global Innovation Index 2014. The Human Factor in Innovation. Available at: http://global-indices.insead. edu/gii/documents/GII2014report.pdf accessed on 12.12.2016.

[24] The Global Innovation Index 2015. Effective Innovation Policies for Development. Available at: https://www. globalinnovationindex.org/userfiles/file/reportpdf/GII-2015-v5.pdf accessed on 12.12.2016.

[25] The Global Innovation Index 2016. Winning with Global Innovation. Available at: https://www.global innovationindex.org/gii-2016-report accessed on 12.12.2016.

[26] TOMKOVA, J.: How Is Ukraine Advancing In E-Government And E-Democracy? 2016. Available at: http://odessare view.com/ukraine-advancing-e-government-e-democracy/ accessed on 28.12.2016.

[27] UNESCO: Towards Knowledge Societies, 2005. Available at: http://unesdoc.unesco.org/ images/0014/001418/ 141843e.pdf accessed on 11.12.2016.

[28] USAID CEED II Moldova and GIZ GmbH. 2014. Competitiveness Assessment of Moldovan IT Services Industry. November 2014. Available at: http://www.mtic.gov.md/sites/default 
/files/staticdocuments/competitiveness-assessment-of-moldovan-it-services-industry.pdf accessed on 14.12.2016.

[29] Webster F. Theories of the information society. $3^{\text {rd }}$ ed. Taylor $\&$ Francis Group. Routledge. 2006,323 p.

[30] World Bank Institute (WBI) 2007. Building Knowledge Economies. Advanced Strategies for Development. Available at: http://siteresources.worldbank.org/KFDLP/Resources/4611971199907090464/BuildingKEbook.pdf accessed on 11.12.2016.

[31] World Economic Forum: The Global Information Technology Report. (WEF GITR) 2015. Available at: http://www3.weforum.org/docs/WEF_Global_IT_Report_2015.pdf accessed on 11.12.2016. 